\title{
RENEWING NEW ZEALAND UNIONS: THE SERVICE AND FOOD WORKERS' UNION \& LIVING WAGE AOTEAROA
}

\author{
Annabel Newman \& Carol Jess \\ Service \& Food Workers Union, Auckland, \& Victoria Management School, Victoria University of \\ Wellington
}

\begin{abstract}
Trade unions and trade unionism are under serious threat in most industrialised countries, in what has been referred to as the 'crisis in trade unionism'. The crisis is common to trade unions across the globe, consisting of a decline in membership and density, coupled with a loss of political influence and social standing. The crisis has been caused by changes in the political economies of the industrially developed nations. Social Movement Unionism (SMU) is one of the strategies to combat this crisis which has been embraced by unions and union movements in many of the Liberal Market Economies (LME). In the context of New Zealand, Jane Parker has looked at the possibility of SMU at a union movement level. However, at a single union level, the Service and Food Workers' Union (SFWU) has engaged with this vision of renewal through participation in the Living Wage Movement Aotearoa New Zealand (LWANZ).

This paper will seek to place the SFWU'S engagement with this campaign within a theoretical framework of union renewal; that is, a re-imagining of trade union relationships in order to (reJgain power along various dimensions. We will further consider the SMU literature and will draw on three concepts identified by Ross in her analysis of social unionism: the ethos, or "collective action frame"; the strategies or "repertoire"; and, the "internal organisational practices", and how these interlink with the literature on union renewal. Of particular note will be the response of both the union and non-union participants in the LWANZ to the development of their relationships, and whether and how this is contributing to the successes of LWANZ and of union renewal.
\end{abstract}

\section{Introduction}

Trade unions have played various important roles in the political economy of industrialised, capitalist economies. These can be summarised as follows: providing a measure of democracy in the workplace through collective voice; providing a countervailing measure to the socio-economic power of capital; and acting as a "sword of justice" by fighting for the vulnerable in society and, through this, articulating values which provide aspirations for a different society (Gumbrell-McCormick \& Hyman 2013). Despite all these contributions, trade unions and trade unionism are under serious threat in most industrialised countries. This threat has been referred to as the 'crisis in trade unionism'. 
The crisis is common to trade unions across the globe, consisting of a decline in membership and density, together with a loss of political influence and social standing. The crisis has been caused by changes in the political economies of the industrially developed nations, in particular by changes resulting in labour markets becoming much more diffuse with the result that traditional trade union members - male, full-time, permanent employees in heavy industry and manufacturing - have come to comprise a smaller proportion of the labour market. Unions have used many different strategies to attempt to combat this crisis, and this paper will look at an example of one of those strategies, Social Movement Unionism (SMU), in the form of the Service \& Food Workers' Union Nga Ringa Tota's (SFWU) participation in the Living Wage Movement (LWM). First we will discuss the nature of "union renewal" in light of the crisis, then the general concept of SMU and an analytical approach to its discussion. Further this paper draws on the findings from a 2013 survey amongst representatives of the various organisations involved in the early stages of the LWM to illustrate the "collective action frame" and "repertoire of strategies" (Ross 20087) adopted and to provide an insight into the significance of these early steps towards a Living Wage in New Zealand. This survey explored the motivations and considerations behind the organisations' engagement in a broad-based coalition, the perceived benefits of that engagement, and the risks and challenges it posed (Newman, Tunoho, \& Brown, 2013). Further, we will discuss Ross' third point of analysis, the union's "internal organising practices", with a view to determining what, if any, changes have been brought about by participation in LWM.

\section{Union Renewal}

It may have become trite to say that union renewal is multi-faceted (Beherns et al 2004, GumbrellMcCormick \& Hyman 2013 for examples). The many strategies adopted by unions globally in the pursuit of renewal encompass the broad categories of organising, workplace and social partnership, and social movement unionism (SMU).

In attempting to create a theoretical framework for the concept of union renewal, we can look to the national context in which each union, and union movement, acts. As Gumbrell-McCormick \& Hyman (2013) have said, it is impossible to understand unions in isolation as they are embedded, at a national level, in four main types of relationship: with their own members and constituents; with employers; with governments; and with "civil society" or "public opinion". Each union, or national union movement, has a different relationship with each of these and so the relevant conception of renewal will depend upon reflection and consideration of what relationships currently exist and which of those can, and should, be influenced to change. Indeed, there may even be opportunities to create new relationships as part of, or the aim of change.

These four types of relationship also echo in part the four dimensions of power discussed by Behrens at al (2005) in their conceptualization of revitalization: membership, economic, political, and institutional. They conceive of revitalisation as (re-) gaining power along the various dimensions that capture these main orientations of spheres of union activity. See Figure 1 for a graphical depiction of these frameworks.

\section{Figure 1 Dimensions of union renewal}




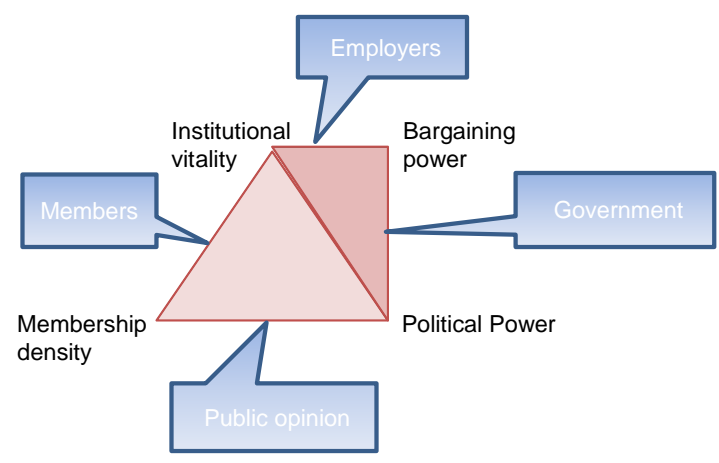

\section{The Concept of SMU}

Social movement unionism (SMU) as a concept is based on the idea that (a) the profile and relevance of trade unions as bodies concerned with social justice will be raised and (b) brought to new constituencies through alliance-building with civil groups and other social movements outwith the workplace (Parker 2011).

SMU "is a 'third type' of unionism distinguished from economism and political concerns (Scipes 1992). "In this conception, advancing the interests of union members necessitates a more fundamental confrontation with the political and economic logic that contributed to the union crisis in the first place" (Parker 2011, 393 citing Hyman 2007). The first examples of such alliance building with groups who are not connected to the workplace were, as Parker (2011) cites, the "Justice for Janitors" campaign in the USA. This could be described as the forerunner to the Living Wage campaigns which have been taken up in the UK, and in NZ. Tattersall (2010) has said that SMU takes a broader perspective in which workers' struggles feature as part of many efforts to qualitatively change society. As Parker (2011) notes, in the SMU literature Dibben identifies three ways in which unions can engage with SMU: a) internal grass roots democracy, b) reaching out to other social groups and c) pursuing broad social justice aims.

When looking at the re-imagining of unions as democratic actors, rather than purely economic ones, Behrens et al have suggested that "as market regulation replaces government regulation, the scope of the issues citizens exercise influence on is reduced, and democratic workplace representation might serve as a substitute". This conception of unions is akin to the original idea of industrial democracy as a "training ground" for active participation in wider society. This ties in with the idea of unions being part of the social capital of a society. Social capital includes features of social organisations such as trust, norms and networks that can improve the efficiency of society by facilitating coordinated actions. (Puttnam 1993, in Behrens et al 2004). Such coordinated action may well also involve the role of unions as a counterbalance to the dominant political and economic ideas and ideologies, therefore broadening the spectrum of political discourse.

The idea that workers' interests extend beyond the workplace is not new, however most union members' fees simply support servicing current fee-paying members in bargaining and problem resolution. Any attempt to move away from the narrow business union models towards SMU leads to issues with the definition of the union's "legitimate" constituencies, as the balance has to be kept between maintaining the confidence of the current membership while attracting new and diverse constituencies as potential members through the extension of the union's role beyond the workplace. As Ross points out, there are plenty of examples where social unionism is what happens "outside of bargaining" and is not considered core union work (Ross 2007; 22). The SFWU, for example, invests $15 \%$ of its income in activities beyond core services and much of the remaining income supports 
recruitment, bargaining and problem resolution (Ryall 2014). It is a complex picture for many unions where activities relating to social unionism and business unionism (ie economistic factors) are interwoven, the former often subsumed by the latter. It is also a picture that presents ideological tensions because, as Ross notes, business unionism by default accepts, or is complicit in, a conservative ideology of the status quo, where union officials seek to improve workers' lot within the current capitalist framework (Ross 2008; 132).

\section{Analytical Framework}

As with many of the concepts in trade unionism, SMU is not singular, and "social unionism's precise meaning and implications remain vague for both unionists and academics" (Ross, 2007: 17). Ross has used concepts from social movement theory to create an analytical framework within which the differing examples of SMU can be assessed and critiqued. This framework consists of a) the ethos or collective action frame used to rationalise union activity; b) the repertoire or strategic means used to act on that ethos; and c) the internal organisational practices and power relations which shape who is involved in defining and carrying out union goals and activities (Ross 2007).

\section{SFWU Strategy}

In line with the definition of renewal which sees SFWU attempting to make new relationships with community groups beyond the workplace, the Living Wage campaign was an initiative of the SFWU that recognised the limitations of current organising practices and aimed at union renewal by drawing on the power of civil society working through coalition. For over a decade the SFWU has been an advocate of a form of unionism called the "Organising Model" (Hurd, 2004) and this is bedded in its kaupapa that talks of being an "organising union"

"That means we are a collective of workers who are about improving the lives of workers and working for a fair and just society by organising for strength, power and unity on the job, in our industries, our communities and society as a whole."

During that period, the union experienced a gradual decline in membership and poor bargaining outcomes characteristic of private sector unions in developed nations. While an important mechanism for a new conversation about building workplace power, the organising model was not a panacea, as SFWU Secretary John Ryall notes:

"I think the powerfulness of the concept of the "organising union" was founded on the point that if there was no state support, even if there were no employer fees deductions, that there would still be workers talking unionism and organising collectively on their jobs and in their communities. I think that this concept requires regular renewal..."

SFWU joins many other unions around the world that have experienced the limitations of the organising model's prescription for union renewal (Ross, 2008: 129). Whether this is failure of leadership to ensure its democratic aspirations are realised in practice (Ince 2010) or, as Johnson has identified, a failure to address the true purpose of the model, the lack of major or sustainable breakthroughs and membership growth is well critiqued in the literature (Hurd, 2004, Johnson, 2001, Ross, 2008).

The Living Wage Movement has emerged in the context of neoliberal legislative constraints on unions and comprehensive work transformation, where unions have struggled to build power to transform the lives of workers (Rosenberg, 2011). The free market has not lifted significant number of workers out of poverty (Perry, 2013). In 2013 in NZ, 91,500 workers lived on the minimum wage and 573,100 
earned less than the then Living Wage rate of $\$ 18.40$ per hour (Ministry of Business and Innovation, 2013). The current bargaining framework under the Employment Relations Act 2000 illustrates the current legislative constraints; many of the lowest paid workers are employed by agencies, contractors or franchisers and in each of these cases the funder of their wages is not required to sit at the negotiating table, is at arm's length from industrial action and invariably argues that they are not responsible for the "non-core" workforce. For example, commercial cleaners in the 2013 collective bargaining round secured an agreement that any funding increase would be passed on to the cleaners, but winning a Living Wage was out of the question when the service contract predetermined the scope of negotiated increases. In short, those who have the power to pay are not captured by the law. This background shows how the diagnosis of the problems which require collective interventions and transformation (Ross 2007; 19) was arrived at by the union.

\section{The Survey}

In 2013 a survey was sent to the participant organisations in the Living Wage Movement in New Zealand. This survey was intended to explore the reasons why diverse and often financially stretched organisations had come together to jointly pursue policies for the reduction of poverty and inequality (Newman et al 2013).

The questions asked were:

1. Why was your (union/faith group/NGO) prepared to work together in this campaign to work in this way?

2. What are the considerations if you join in a broad based communicate based campaign requiring partnership?

3. What are the benefits from working in this way?

4. What are the risks?

5. What are the challenges?

Responses were received from fourteen organisations. The responses will be used below to illustrate how Ross' analytical framework can be applied to the Living Wage Movement. (Newmal et al 2013)

\section{Building a collective action frame}

The Living Wage Movement involves a paradigmatic shift for unions to engage in a form of social unionism that is not contained within, or controlled by, the union organisation itself. It captures a collective action frame of social unionism that places workers within their communities, that grounds them in citizenship, recognising social and economic influences on their lives from beyond the workplace. The movement aspires to a democratic project that changes society and not just employment arrangements in workplaces. The conversation extends beyond the impact of low wages on workers and their families to the impact of low wages on society as a whole. The discussion begins with the question of "who pays for low pay?" The answers depend on the community present but one solution shared across the diverse organisations of the Movement is a Living Wage. A diagram familiar to many in the movement captures the ever expanding nature of the conversation around the Living Wage ${ }^{1}$.

\footnotetext{
${ }^{1}$ Adapted from a tool used by Deborah Littman, lead organiser, Metro Vancouver Alliance
} 


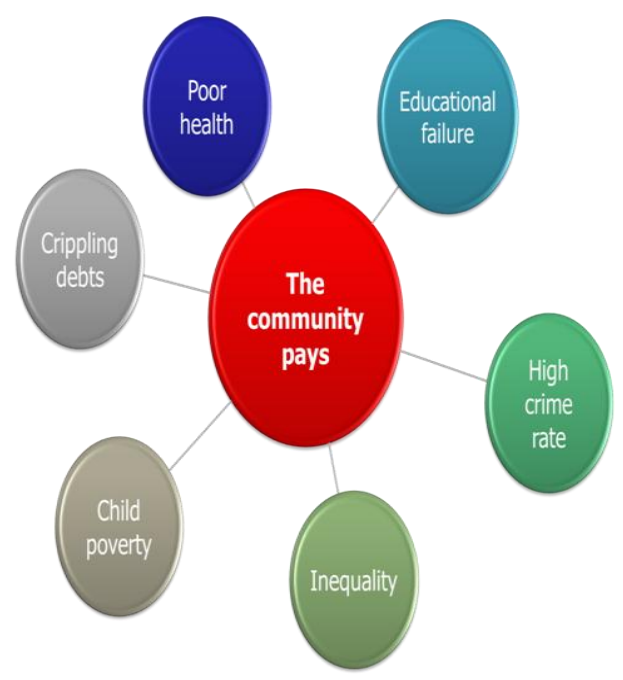

The ethos of active citizenship within the movement is illustrated in the comments of survey participants from each of the three groups (faith, union and community) describing why they chose to engage in a broad-based coalition for a Living Wage. A faith-based religious group respondent says:

"Theologically, we believe that God is already present in the world, calling us to join with other people of good will to work for social justice" (Newman et al., 2013; 125).

The different but complementary interests of unions were expressed in the following way:

"With the LW [Living Wage] campaign, unions have the opportunity to significantly augment their efforts to raise living standards and build relevancy with broad tracts of the (unorganised) community as a force for fairness and justice at work and beyond" (Newman et al., 2013; 125).

A secular/community representative articulated their interests as:

"Our members see health in the broadest sense. This means taking a holistic approach to primary health care. We view pushing income and employment [concerns] as integral parts of a person's overall wellbeing" (Newman et al., 2013; 125).

The comments reflect a common vision of social justice across diverse organisations each with a quite distinct purpose.

Unions generally share this vision of social justice, but their role in society has been largely confined to representation and advocacy for fee-paying union members. There is a history of service-focused unionism or "business unionism" which narrowly defines workers' interests focused on membership (Ross, 2008; 132) and leads to issues with allocating the scarce resources of unions. Increasing membership numbers increases the burden of advocacy and consumes the time of paid organisers who become both defined and limited by this focus.

Unions are seeking renewal and growth but are constrained by this historical straight jacket of bargaining and representation. Stepping out of this straight jacket requires a new "collective action frame" defined by a broader vision of social justice, encompassing a more diverse community, and leading to engagement in a new "repertoire" of action.

\section{A new repertoire}


In its prognostic framing (Ross 2007: 20), SMU identifies a repertoire of strategies distinct from bargaining to match the more expansive definition of workers' interests as citizens. That repertoire includes a commitment to social movement actions such as non-partisan lobbying and coalitionbuilding across community, faith and unions (Ross, 2008; 135). This is different from the more traditional expressions of political engagement familiar to NZ Labour Party union affiliates, such as the SFWU and the Engineering, Printing and Manufacturing Union (EPMU). Just as the organising model has proved limited in increasing levels of unionisation, so political party alignment (while not without some benefits for the SFWU, such as protection for some contracted workers during a sale or transfer of business) has proved limited in translating votes into significant economic gains for workers.

This type of political engagement has been common for European trade unions, and Upchurch et al have discussed the options open to unions in the United Kingdom, France and Germany in light of the changing nature of the political climate generally, and historically social democratic parties in particular (Upchurch et al 2009). They have suggested that unions may exploit the opening up of a gap between the trade union movement and the social democratic parties in order to liberate themselves from the institutional and ideological fetters of the Keynesian welfare state in order to re-establish themselves as autonomous "movements" in civil society. (Upchurch et al 2009: ).

Despite being a Labour party affiliate, the SFWU therefore intentionally stepped beyond these traditional strategies. After looking at the international experience of building a broad-based coalition in the UK and US, key principles emerged to provide an important touchstone for the new campaign that both challenged the Union's traditional practice but also resonated with its workplace leaders. These principles would firmly ground workers in citizenship and opened up the space for quite a new repertoire of strategies. These principles were:

- The importance of a community organising model that builds sustainable relationships across civil society, rather than rallying groups around an issue.

- Equal ownership of the Living Wage concept by secular/community, faith-based religious groups and union groups.

- The need to build local organisation around local relationships and issues.

- The joining of groups or organisations, rather than individuals to the Movement.

- The creation of a separate identity for the Living Wage campaign so it was firmly grounded in a broad-based community alliance.

- The importance of a non-party political stance by the Movement (Newman et al, 2013).

The secret to success of social unionism for the SFWU lies in the relationship between the goal of poverty reduction and the tactics applied to win the Living Wage.

A key distinguishing feature of the LWM is that it is a coalition, rather than a charity (Ross 2007; 26). Coalitions deliver to both parties, one does not join the other but they take action together. A faith group survey respondent expresses this difference between charity and coalition:

"The relationships among people working together are great. It's not a charity model because the people who benefit directly are part of the movement rather than recipients, and the rest of us benefit indirectly by living in a more just society" (Newman et al., 2013; 127). 
Articulating the commitment to working together in coalition and relinquishing control in order to do so, a union respondent says:

"We need to be prepared to work hard with our partners to build new strategies that involve working together to beat poverty wages. Unions will not have all the power in control in this process, it must be shared" (Newman et al., 2013; 127).

The seemingly simple description of charity versus coalition belies the long, slow and deeply challenging process for groups working in coalition. Here we want to draw on the survey to illustrate this. The first challenge is bringing together diverse groups around a common interest, as one faith respondent tells it:

"Because of our theology, we expect to find God's presence in others, and to learn new insights from them. We find that many of our assumptions about people who are 'different' to us theologically, politically and socio-economically need re-examining" (Newman et al, 2013; 126).

The second challenge is accepting slow results as a community respondent says:

"Broad-based campaigns bring together diverse organisations and therefore there is a period in which groups must invest in building relationships and not make assumptions about common values delivering a commitment..." (Newman et al., 2013; 127).

This challenge goes to the heart of union survival because building relationships takes time and time is money. The reality of the new approach is captured by a Union respondent:

"You need to build up trust, you need to understand and listen to the issues the other groups bring with them, you need to be in the campaign for the long-haul and you need to make an investment in money and resources that is not going to deliver immediate financial return to your organisation..." (Newman et al., 2013; 127).

The third challenge was ensuring the coalition was a meeting of equals; of organisations that shared responsibility and ownership for the Movement. Working as partners was a condition and an expectation of some survey respondents, as this faith group respondent reports:

"We tend to make decisions about issues and involvement depending on an emerging common mind of the nature of a form of oppression, a desired outcome, and with whom we can therefore form any degree of partnership" (Newman et al., 2013; 127).

As one faith respondent highlights deep and respectful relationships cannot be taken for granted:

"We were amazed that faith communities were considered to be a vital part of the Living Wage campaign. We are used to working in alliances but the particular contribution of faith communities in terms of both the people in the communities and the theological/justice basis of faith communities are not usually appreciated. So usually you join and "check your faith perspective at the door" (Newman et al., 2013; 127).

Without exception, the respondents shared a hope that by taking action together they would achieve a more just society.

"What's revealing to date is the very significant amount of 'common ground' between the participating groups and organisations. It is clear that there is much we can work together on - and therefore build 
real synergies and power - to drive consciousness and action around the realisation of the Living Wage agenda" (Newman et al 2013, p. 127)

Trusting relationships between leaders of diverse organisations in civil society underpin the new Movement for a Living Wage. The tactic of coalition-building has been effective in establishing a new approach to social unionism, with an early victory at Wellington City Council and a new and lively public debate about wages and the working poor in NZ. Unions being active in community and with community, has been a positive experience for some community and faith-based religious groups, as one faith group respondent notes:

"The Unions are amazingly generous, hardworking and effective in the ways they are supporting the campaign. It's been wonderful to have their experience in organising..." (Newman et al., 2013; 127)

However, the question remains whether unions themselves are changing as a result of their engagement with civil society and therefore, whether a new form of social unionism in this country is emerging.

\section{Internal organisational strategy}

As noted above, Dibben's first proposition about how unions could engage with SMU involved internal grass roots democracy. Greater democracy within Unions is not intrinsic to either social unionism (Ross, 2008) or to the popular organising model (Ince, 2010). Is it the case that involvement with the LWM has created space for change within the SFWU?

Building a broad-based coalition of civil society based on trusting relationships and activating the participant organisations around common goals is a democratic project. As the father of community organising in the United States, Saul Alinsky, says: "The fire, the energy, and the life of democracy is popular pressure"(Alinsky, 1946: 196). The Living Wage Movement reaches beyond the workplace to ensure more people and more groups exert pressure on decision-makers, delivering a more just and accountable system of government. Achieving this is dependent upon each of the participant groups individually, as much as the participant groups acting in unison for a Living Wage. The role, therefore, of unions and their own internal organising practices cannot be ignored. As Ross writes:

"The particular connection between framing, strategizing, deciding and implementing can have important implications for the extent to which social unionist practices are transformative or are building greater movement capacity"(Ross, 2007, p. 27).

The Living Wage Movement was an initiative of a union seeking new ideas for renewal and many other unions have joined with moral, if not financial, support. The idea, issues, actions and even implementation have been framed and led by union leaders (albeit increasingly alongside community leaders).

The left-leaning Wellington City Council would probably not have advanced and voted for a Living Wage without the pressure of the local Living Wage group, but it was not a product of active participation of members in the framing and implementation of strategies. It was, rather, a product of an emerging progressive new council, a lively debate about poverty wages in the community and an emerging community movement rather than the strategy of an organised broad-based alliance for a Living Wage. The debate about a Living Wage at Auckland Council was put on the agenda following eight election candidate events at which the Mayoral prospect, Len Brown, committed to a Living Wage. However, 80 union members attending a meeting is not mass mobilisation and members have not participated in organising the campaign. Applying Ross's categorisation of internal organisational 
practices, social unionism within the Living Wage Movement is leadership-focused and not membership-focused/mobilisational, or membership-focused/democratising (Ross 2007; 27).

Engagement with the LWM is an attempt by the SFWU to move away from the organising model as union strategy. In terms of internal organisation, the organising model has a primarily inward focus on involving workers in planning and carrying out union campaigns, mobilising members through action, and recruiting one-to-one. As discussed in Gumbrell-McCormack and Hyman (2013; 52) the model as developed in North America assumes a close connection between recruitment and mobilisation. On the other hand, SMU focuses externally on workers as citizens in a broader community. Either approach can be membership-focused or leadership-focused (Ross 2007; 27).

LWM's guiding principles of relational organising in a broad-based coalition may be more compatible with a membership-focused practice that can resource mobilisation and actions to assert public pressure on decision-makers. An active and powerful membership serves the workplace and the community, or as Alinsky says "an interested and participating people is popular pressure!" (Alinsky, 1946; 196) Addressing the "internal organisational practice" may hold the key to bridging the gap between a new community-orientated social unionism and the other approaches that coalesce within unions, such as servicing and the organising model. This gap, unattended, can be a breeding ground for ideological tensions between those advocating a traditional "fortress unionism" and those advancing a "battle plan" for all citizens (members and non-members alike). It can also be a source of internal resource competition between core servicing activities and non-core community activities in unions already financially stretched.

The reason for the glacial progress in delivering membership growth for the initiating Union may indeed lie in this final and very important concept of internal practice and its transformative capacity. While Ross argues that members can be mobilised on conditions largely determined by leaders (2007; 28 ) it is worth considering the implications of failing to challenge a leadership-focused model. At best this leader-dependence could create a chilling effect on the commitment of the union activists within the Movement as they become disempowered, disillusioned or disconnected; at worst, it could destroy the gains made in establishing a foundation for the new social unionism through the revised collective action frame and a new repertoire of strategies.

\section{Conclusion}

This paper has looked at the SFWU's engagement with the Living Wage Movement in New Zealand as a strategy for union renewal. The strategy is one based upon the concept of Social Movement Unionism, as moving the union beyond its relationships with members and employers in collective bargaining, to a broader social coalition based on social justice goals. Further, survey responses from fourteen participating organisations have been used to exemplify Ross' framework for analysing social movement unionism, and confirm the diagnosis or the issue, the prognosis required and the opening up of a collective action frame, expanding the SFWU's repertoire of action. The responses from the participating organisations show that success has been found in reaching out to the broad alliance with community organisations and the ongoing discovery of wider aims for societal change in common are a large measure of this.

The goal, however, of greater union strength, or even internal organisational change has not yet come about. This may be because, as is acknowledged by the participants, building such alliances is a slow process, and the benefits of those alliances are not necessarily immediately gained. There also remains the issue that this strategy for the SFWU has been leadership-led, and while it has engaged participants outside the workplace in a coalition with unions, it has engaged to a lesser extent the 
SFWU members directly. This is a potential source of conflict, both ideological and financial, between members who wish to see their union act in their interests before, or to the exclusion of, non-members and the union leadership who see a broader role for unions in the twenty-first century.

There is much potential for further research here, either across the LWM to update and widen the Newman et al survey, but also within the union membership itself. If the union has already taken steps to change its relationship with community groups, this will likely have some impact on the relationship with current members. To what extent the membership understand and accept the union strategy is also of interest in the study of union renewal, because while attracting new members to the union movement remains important, current members must also be retained if the movement is to regain the political and social standing it once exercised.

\section{References}

Alinsky, S. D. (1946). Reveille for radicals (1969 ed.). New York: Random House.

Behrens M, Hamann K, Hurd, R (2004) Conceptualizng Labour Union Revitalization in Frege C and Kelly J (2004) Varieties of Unionism: Strategies for Union Revitalizaiton in a Globalizing Economy

Gumbrell-McCormick R \& Hyman R (2013) Trade Unions in Western Europe Hard Times, Hard Choices Oxford University Press, Oxford UK

Hurd, R. W. (2004). The rise and fall of the organizing model in the U.S. [Electronic Version]. Cornell University ILR School. Retrieved January $10 \quad 2014$ from http://digitalcommons.ilr.cornell.edu/articles/301/.

Hyman, R (2007) How can unions act strategically? Transfer: European Review of Labour and Research $13, \mathrm{p} 193$

Ince, A. (2010). Beyond 'Social Movement Unionism'? Understanding and assessing new wave labour movement organising [Electronic Version], 1-60. Retrieved November 10, 2013 from http://reinventinglabour.wordpress.com/2010/06/05/beyond-social-movement-unionismince/.

Johnson, P. (2001). Organize or what?The resurgence of labor as a citizenship movement. In L. Turner, H.C. Katz \& R.W. Hurd (Eds.), Rekindling the Movement: Labor's quest for relevence in the 21st century (pp. 27-58). Ithaca, New York: Cornell University Press.

Ministry of Business and Innovation. (2013). New Options Doc. March 11, 2013, Summary of the impacts of the minimum wage options for 2013. Wellington: Official Information Act request.

Newman, A., Tunoho, M., \& Brown, E. (2013). The living wage campaign: Collaboration in practice. Paper presented at the Partnership or collaboration: Is there a difference? Downloaded from http://www.pha.org.nz/documents/PHANZ 2013 conference proceedings.pdf).

Parker, J (2011) Reaching out for strength within? "Social movement unionism" in a small country setting Industrial Relations Journal 42:4, p 392

Perry, B. (2013). Household incomes in New Zealand: Trends in indicators of inequality and hardship 1982-2012. Wellington: Ministry of Social Development. 
Ross, S. (2007). Varieties of social unionism: Towards a framework for comparison. Just Labour: $A$ Canadian Journal of Work and Society, 11(Autumn 2007), 16-34.

Ross, S. (2008). Social unionism and membership participation: What role for union democracy? Studies in Political Economy, Spring(81), 129-157.

Ryall, J. (2014). Wellington: Service and Food Workers Union Nga Ringa Tota.

Upchurch M, Taylor G \& Mathers A (2009) The crisis of "Social Democratic" unionism: The "opening up" of civil society and the prospects for union renewal in the United Kingdom, France and Germany Labor Studies Journal 34, p519 